\title{
Observations of the atmosphere and surface state over Terra Nova Bay, Antarctica, using unmanned aerial systems
}

\author{
John J. Cassano ${ }^{1,2}$, Mark W. Seefeldt ${ }^{1}$, Scott Palo ${ }^{3}$, Shelley L. Knuth ${ }^{4}$, Alice C. Bradley ${ }^{3}$, \\ Paul D. Herrman ${ }^{5}$, Peter A. Kernebone ${ }^{5}$, and Nick J. Logan ${ }^{5}$ \\ ${ }^{1}$ Cooperative Institute for Research in Environmental Sciences, University of Colorado, Boulder, CO, USA \\ ${ }^{2}$ Department of Atmospheric and Oceanic Sciences, University of Colorado, Boulder, CO, USA \\ ${ }^{3}$ Department of Aerospace Engineering Sciences, University of Colorado, Boulder, CO, USA \\ ${ }^{4}$ Research Computing, Office of Information Technology, University of Colorado, Boulder, CO, USA \\ ${ }^{5}$ Aerosonde Pty. Ltd, Melbourne, Australia
}

Correspondence to: John J. Cassano (john.cassano@colorado.edu)

Received: 7 November 2015 - Published in Earth Syst. Sci. Data Discuss.: 1 December 2015

Revised: 27 February 2016 - Accepted: 4 March 2016 - Published: 18 March 2016

\begin{abstract}
In September 2012 five Aerosonde unmanned aircraft were used to make measurements of the atmospheric state over the Terra Nova Bay polynya, Antarctica, to explore the details of air-sea ice-ocean coupling. A total of 14 flights were completed in September 2012. Ten of the flight missions consisted of two unmanned aerial systems (UAS) sampling the atmosphere over Terra Nova Bay on 5 different days, with one UAS focusing on the downwind evolution of the air mass and a second UAS flying transects roughly perpendicular to the low-level winds. The data from these coordinated UAS flights provide a comprehensive three-dimensional data set of the atmospheric state (air temperature, humidity, pressure, and wind) and surface skin temperature over Terra Nova Bay. The remaining UAS flights during the September 2012 field campaign included two local flights near McMurdo Station for flight testing, a single UAS flight to Terra Nova Bay, and a single UAS flight over the Ross Ice Shelf and Ross Sea polynya. A data set containing the atmospheric and surface data as well as operational aircraft data have been submitted to the United States Antarctic Program Data Coordination Center (USAP-DCC, http://www.usap-data.org/) for free access (http://gcmd.nasa.gov/getdif.htm?NSF-ANT10-43657, doi:10.15784/600125).
\end{abstract}

\section{Introduction}

Terra Nova Bay, Antarctica, is located in the western Ross Sea (see Fig. 1 for a geographic map of the region) and is an area renowned for its strong downslope winds (Bromwich, 1989; Parish and Bromwich, 1989; Bromwich et al., 1990, 1993; Gallee and Schayes, 1994). These strong winds are responsible for creating a region free of sea ice, adjacent to the coast, which occurs periodically throughout the winter, known as the Terra Nova Bay (TNB) polynya (Kurtz and Bromwich, 1983; Bromwich and Kurtz, 1984; van Woert, 1999; Ciappa et al., 2012). The TNB polynya varies in size from 3000 to $7000 \mathrm{~km}^{2}$ during the winter (Hauser et al.,
2002) and is an important element of the regional climate since strong air-sea coupling occurs over the open water, especially in winter, as cold, dry continental air flows over the relatively warm open water. This air-sea coupling provides a source of heat and moisture for the atmosphere (Knuth and Cassano, 2014). As the strong, cold, dry offshore winds blow across the TNB polynya energy is extracted from the open water resulting in the formation of sea ice, which is advected away from the coast by the strong winds (Morales Maqueda et al., 2004; Petrelli et al., 2008; Rusciano et al., 2013). The formation of sea ice results in salt rejection to the ocean increasing the density of the near-surface water (Buffoni et al., 2002; Kern and Aliani, 2011). This cold, saline water forms 


\section{Ross Island Region / Terra Nova Bay}

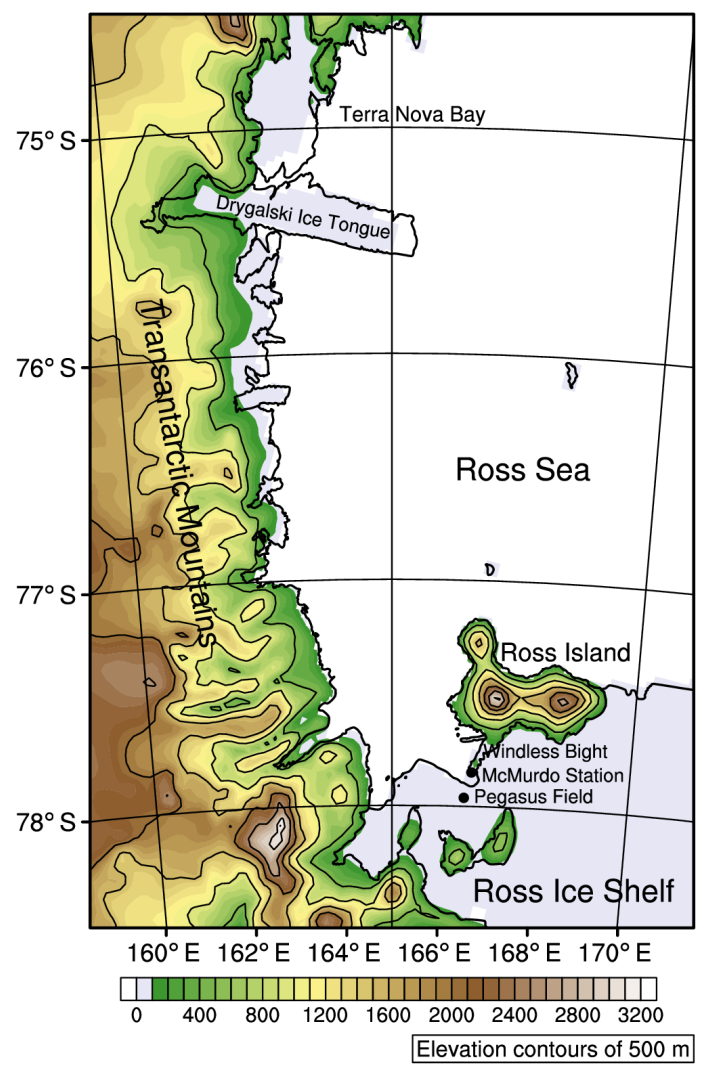

Figure 1. Geographic location map for the Ross Island and Terra Nova Bay regions.

Antarctic bottom water, the densest water in the world ocean, which is critical for the global thermohaline circulation (Orsi and Wiederwhol, 2009; Fusco et al., 2009).

Observational data for studying the coupled air-sea iceocean processes described above are limited due to the harsh environmental conditions in this region of the Antarctic. Automatic weather stations operate year round at locations along the coast and further inland from Terra Nova Bay (Lazzara et al., 2012; Grigioni, 1996), but do not provide observations over the polynya. Ocean moorings have been placed in Terra Nova Bay but do not provide data on the near-surface ocean properties (Cappelletti et al., 2010). Manned aircraft have made observations over Terra Nova Bay and the adjacent areas of the continent during limited duration field campaigns in the austral summer (Parish and Bromwich, 1989). In September 2009 Aerosonde unmanned aerial systems (UAS) were used to make the first late winter measurements of the atmospheric and surface state in Terra Nova Bay (Cassano et al., 2010; Knuth et al., 2013; Knuth and Cassano, 2014). A follow-on field campaign, building on the success of the September 2009 UAS flights, took place during September 2012.
The September 2012 field campaign used five Aerosonde UAS to conduct 14 flights totaling more than 168 flight hours. On five of the flight days two UAS made simultaneous observations of the atmosphere over Terra Nova Bay while flying in both the downwind and cross-wind direction. These flights were designed to provide a comprehensive three-dimensional description of the atmosphere in order to quantify the air-sea coupling occurring over the polynya. Based on the atmospheric state measurements collected by the UAS, estimates of the surface turbulent heat fluxes are possible following the method described in Knuth and Cassano (2014). The three-dimensional atmospheric data collected during these flights will also allow for a thorough description of the horizontal and vertical extent of the strong offshore flow over Terra Nova Bay and estimates of the forcing for this flow over the polynya.

Section 2 describes the Aerosonde UAS and the flight strategy employed during September 2012. The data collected by the UAS and the quality control procedures are covered in Sect. 3. Section 4 discusses the data availability and format. Concluding remarks are provided in Sect. 5.

\section{Description of the Aerosonde UAS and flight strategy}

\subsection{Aerosonde UAS}

The instrument platform for this field deployment was the Aerosonde ${ }^{\circledR}$ Mark 4 UAS (Fig. 2) designed and manufactured by Aerosonde Pty Ltd. of Melbourne, Australia. The Aerosonde ${ }^{\circledR}$ UAS is a small (3.6 m wingspan, $19-21 \mathrm{~kg}$ takeoff weight), robotic, pusher-prop aircraft designed to undertake a wide range of operations in a highly flexible and inexpensive mode (see Table 1 for the specifications of the Aerosonde ${ }^{\circledR}$ UAS). The Aerosonde ${ }^{\circledR}$ UAS has proven to be capable of carrying a variety of instrument packages (Holland et al., 2001) and to perform well under polar winter conditions in the Arctic (Inoue and Curry, 2004; Curry et al., 2004; Inoue et al., 2008) and the Antarctic (Cassano et al., 2010; Knuth et al., 2013). The relatively fast flight speed for a small UAS allows the Aerosonde ${ }^{\circledR}$ UAS to operate in strong winds, which are a frequent feature of the Terra Nova Bay region. In fact, observations were made of wind speeds in excess of the UAS's maximum flight speed of $33 \mathrm{~m} \mathrm{~s}^{-1}$. The Aerosonde ${ }^{\circledR}$ UAS flights were completely robotic, except for take-off and landing, and were under the command of a ground controller, using real-time telemetry, adjusting the operation to meet the needs of the science objectives, changing weather conditions, and avoiding hazards. The ground controller and UAS communicate via $900 \mathrm{MHz}$ radio with a range of $100 \mathrm{~km}$ and by Iridium communication at greater distances.

The Aerosonde ${ }^{\circledR}$ was equipped with instruments to observe the atmospheric and surface state along the flight path (see Table 2 for details). A Vaisala HMP155 was used to 


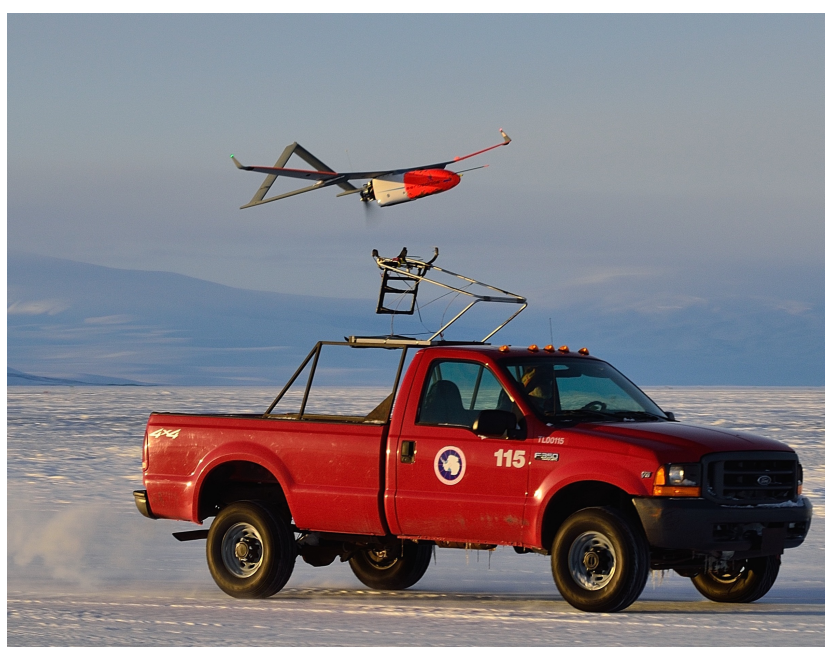

Figure 2. The Aerosonde UAS being launched from a truck at Pegasus Field (photo: J. Cassano).

measure the air temperature and relative humidity at $5 \mathrm{~s}$ intervals. Atmospheric pressure at the UAS flight level was measured with a Vaisala PTB110 pressure sensor. Atmospheric pressure was measured in $1 \mathrm{~s}$ intervals, although the postprocessed output files are in $5 \mathrm{~s}$ intervals. The wind speed and wind direction were calculated indirectly based on measurements from the UAS Piccolo Avionics system indicating the flight heading and speed (see details in Sect. 3). Surface temperatures were measured using the Everest Envirotherm infrared thermometers (models differed slightly between the aircraft). All models measured skin temperatures (top few millimeters of the surface) from flight altitudes up to $300 \mathrm{~m}$. There was a slight cold bias in surface temperature measurement at higher flight levels, likely due to cold sea spray present in the air above the polynya and any use of these data should carefully assess the magnitude of this error based on the flight level.

\subsection{Flight strategy}

Table 3 lists the 14 Aerosonde UAS flights conducted during September 2012. All of the flights originated at the Pegasus Field ice runway $\left(77.9^{\circ} \mathrm{S}, 166.5^{\circ} \mathrm{W}\right)$ located $13 \mathrm{~km}$ south of McMurdo Station, the main base of the United States Antarctic Program. Eleven of the 14 flights were missions to Terra Nova Bay (Fig. 3). Of the 14 flights, 4 collected limited scientific data due to communication or aircraft problems, two were short duration test flights at the Pegasus ice runway that collected minimal data of scientific interest (not shown), and 1 flight made observations over the Ross Ice Shelf and Ross Sea polynya east of Ross Island (Fig. 4). A total of 168 flight hours were completed during this Antarctic UAS deployment. Individual flight durations ranged from less than an hour to $18 \mathrm{~h}$. The main scientific portions of the flights were flown between 100 and $1600 \mathrm{~m}$ above ground level.
Table 1. Aerosonde UAS specifications.

\begin{tabular}{ll}
\hline Wingspan & $3.6 \mathrm{~m}$ \\
Weight & 18 to $21 \mathrm{~kg}$ \\
Payload capacity & 2 to $3.5 \mathrm{~kg}$ \\
Endurance & $\mathrm{Up}$ to $19 \mathrm{~h}$ \\
Range & $1000+\mathrm{km}$ \\
Operating altitude & 100 to $6000 \mathrm{~m}$ a.g.l. \\
Cruise/maximum speed & $22 / 33 \mathrm{~m} \mathrm{~s}^{-1}$ \\
Communications & $900 \mathrm{MHz}$ radio and Iridium \\
& satellite phone modem \\
\hline
\end{tabular}

The primary scientific objectives for this field campaign were to document the three-dimensional state of the atmosphere over the TNB polynya, quantify the modification of the continental air mass as it flows over the polynya, and collect atmospheric state data that allows for estimation of the surface turbulent heat fluxes (Knuth and Cassano, 2014) and terms in the horizontal momentum equation. The TNB Aerosonde UAS flights were launched from the Pegasus Field ice runway and flew north over McMurdo Sound and the western Ross Sea to TNB (Fig. 3). After crossing the Drygalski ice tongue, which marks the southern edge of TNB, the Aerosonde would commence one of two main flight patterns to sample either the downwind evolution of the atmosphere or to document the crosswind variability in the atmospheric state over the polynya.

The first type of Aerosonde missions were designed to fly primarily aligned with the near-surface winds, sampling the downstream evolution of the air mass as it passed over and beyond the TNB polynya. These flights are referred to as downwind transects in Table 3 and the subsequent text. During these downwind transect flights spiral ascent and descent profiles extending from the minimum flight altitude (normally $100 \mathrm{ma.g.1.}$ ) to above the top of the boundary layer (approximately $1600 \mathrm{~m}$ a.g.l.) were completed every 5 to $15 \mathrm{~km}$ in the downwind direction. For most of these flights the downwind transect, including spiral ascent/descent profiles, was flown a second time, 3 to $5 \mathrm{~h}$, after the initial downwind transect. This repeat transect provides data on the time evolution of the atmospheric state and allows for clearer interpretation of spatial versus temporal changes in the observations. The location of the downwind transect over TNB was determined by flying an initial transect between 100 and $200 \mathrm{~m}$ a.g.l. parallel to the coastline at the western edge of Terra Nova Bay. Based on wind data collected during this transect the location of the downwind transect flights was chosen to correspond to the strongest offshore flow. This transect was aligned with the area of strongest offshore flow as this portion of the flow will experience the largest air-sea fluxes.

A second type of Aerosonde mission was designed to sample the crosswind variability of the atmospheric state over the TNB polynya and are referred to as crosswind tran- 


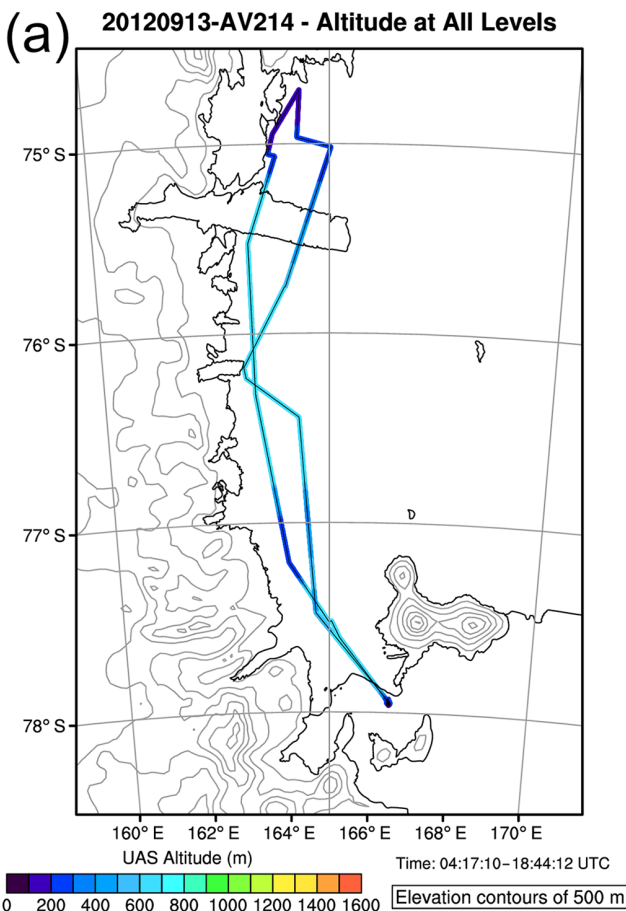

(b) 20120914-AV216 - Altitude at All Levels
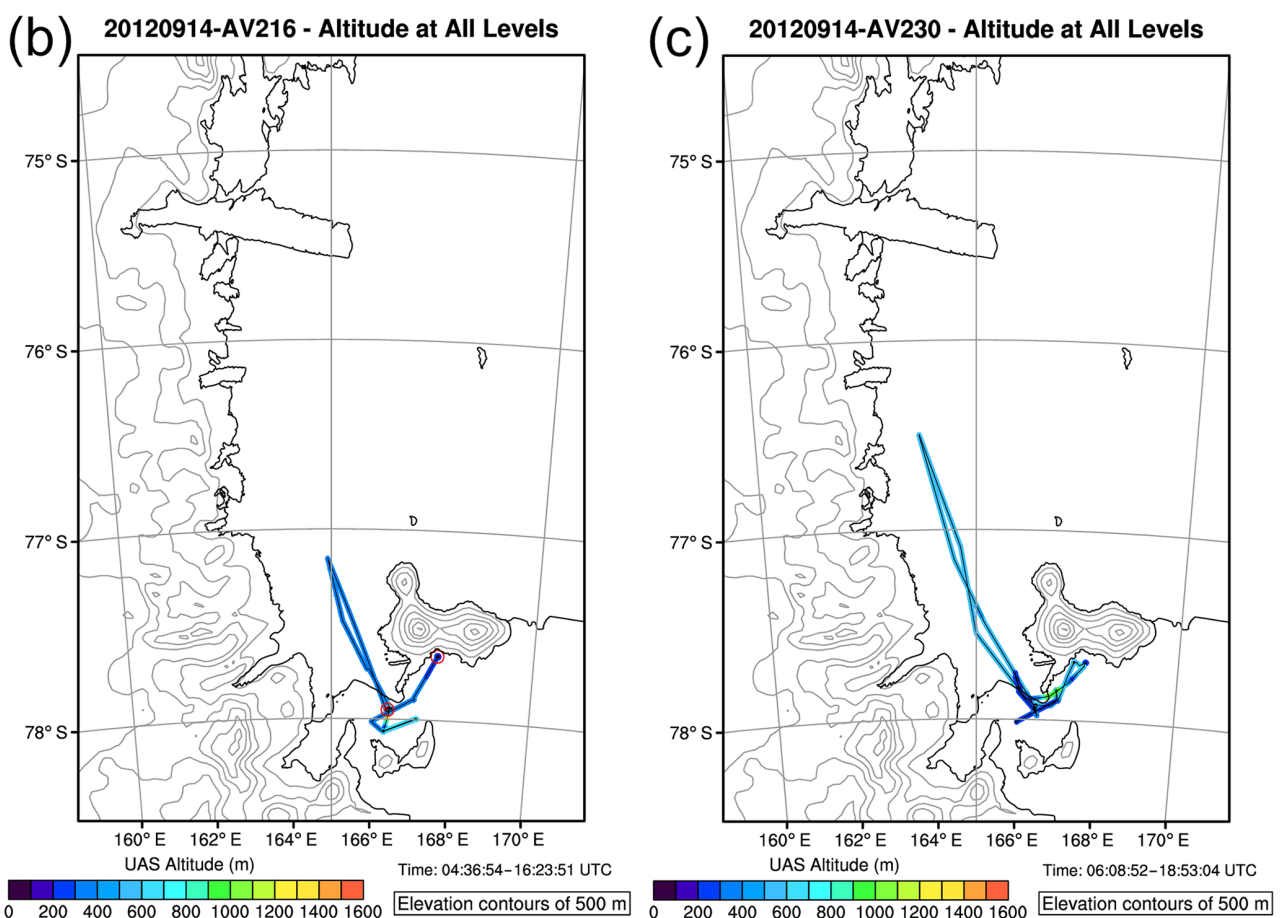

Figure 3. 

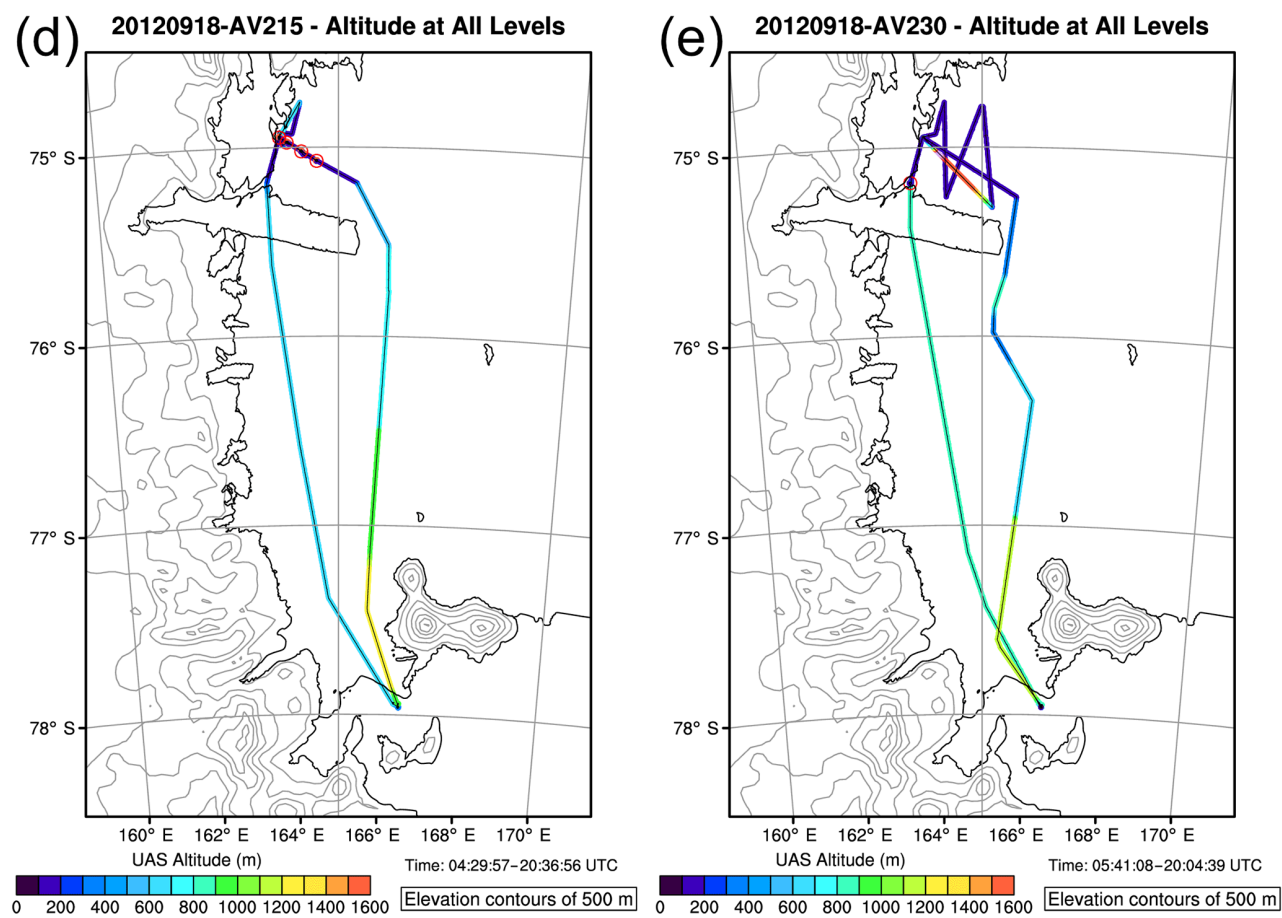

(f) 20120919-AV215 - Altitude at All Levels
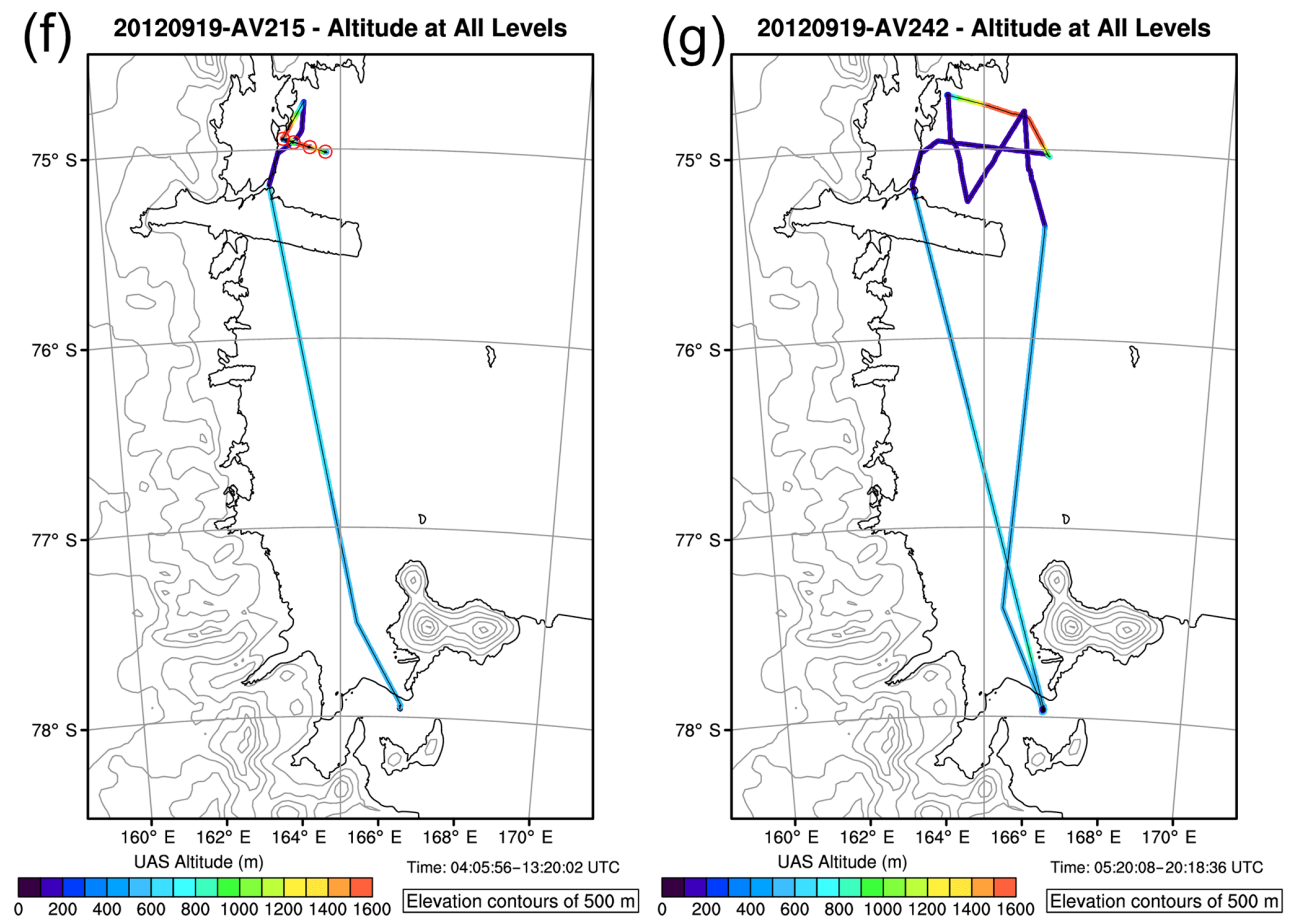

Figure 3. 

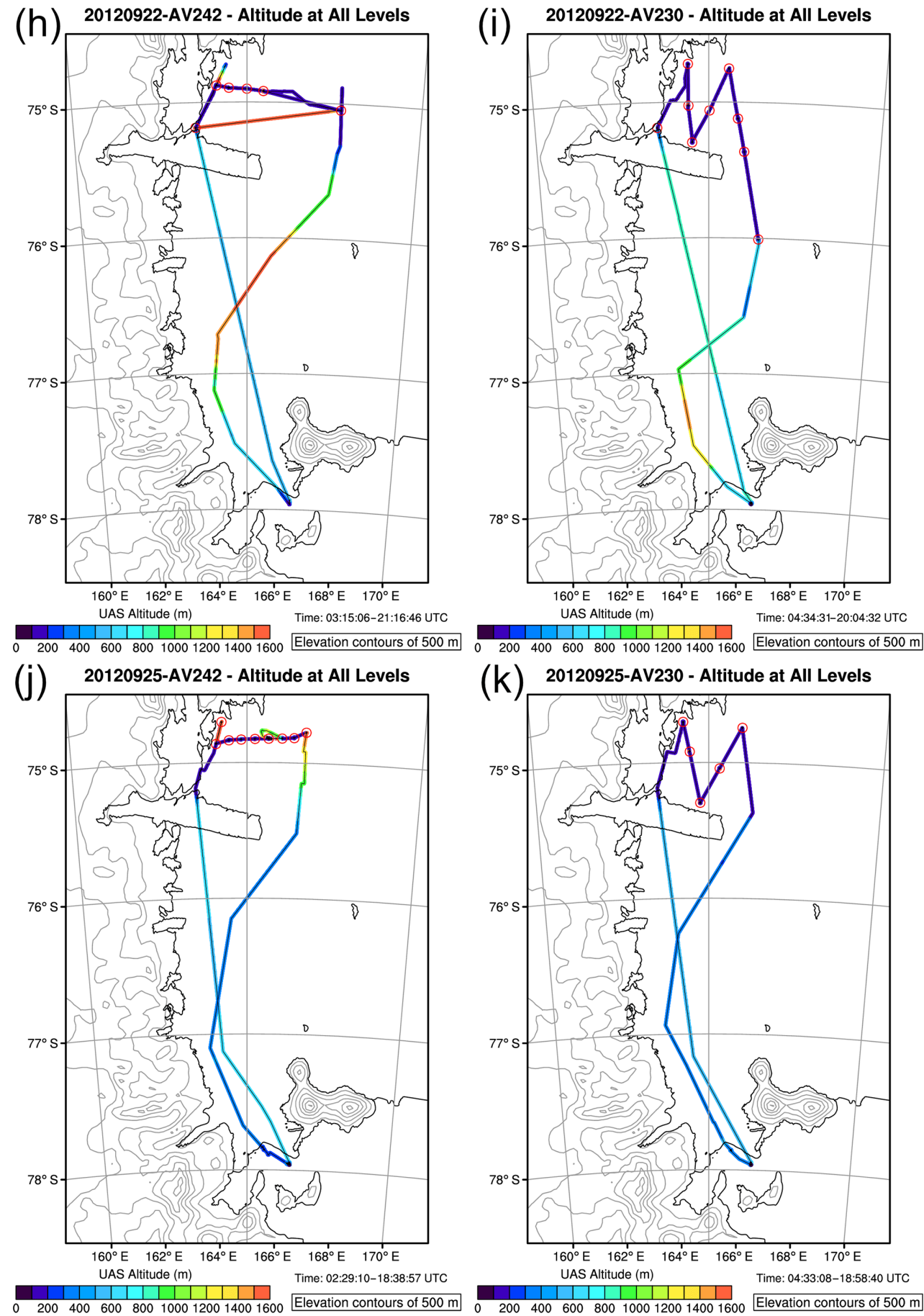

Figure 3. Maps of Terra Nova Bay flights on 13 September 2012 AV214 (a), 14 September 2012 AV216 (b) and AV230 (c), 18 September 2012 AV215 (d) and AV230 (e), 19 September 2012 AV215 (f) and AV242 (g), 12 September 2012 AV242 (h) and AV230 (i), and 25 September 2012 AV242 (j) and AV230 (k). Color shading along flight path indicates flight altitude. Red circles indicate location of profiles. 
Table 2. Aerosonde instrument specifications.

\begin{tabular}{|c|c|c|c|c|c|}
\hline $\begin{array}{l}\text { Meteorological } \\
\text { parameter }\end{array}$ & Sensor & Range & Accuracy & $\begin{array}{l}\text { Sampling } \\
\text { frequency }\end{array}$ & $\begin{array}{l}\text { Sensor time } \\
\text { constant }\end{array}$ \\
\hline Temperature & Vaisala HMP155 & -80 to $60^{\circ} \mathrm{C}$ & $\pm(0.226-0.0028 \times \text { temp. })^{\circ} \mathrm{C}$ & $5 \mathrm{~s}$ & $<20 s$ \\
\hline $\begin{array}{l}\text { Relative } \\
\text { humidity }\end{array}$ & Vaisala HMP155 & $0-100 \%$ & $\pm(1.0+0.012 \times$ reading $) \% \mathrm{RH}$ & $5 \mathrm{~s}$ & $20 \mathrm{~s}$ \\
\hline Pressure & Vaisala PTB110 & $500-1100 \mathrm{hPa}$ & $\pm 1.5 \mathrm{hPa}$ & $1 \mathrm{~s}$ & $0.5 \mathrm{~s}$ \\
\hline $\begin{array}{l}\text { Wind speed and } \\
\text { direction }\end{array}$ & Piccolo Avionics & \multicolumn{4}{|c|}{$\begin{array}{l}\text { Wind speed and wind direction were determined from the UAS Piccolo Avionics } \\
\text { measurements of ground speed, track, and true air speed. Additionally, the aircraft } \\
\text { heading is determined when the UAS changes course. The UAS wind finding } \\
\text { algorithm uses a regression fit based on these measurements to determine wind } \\
\text { speed and wind direction. The estimates degrade over time while the UAS maintains } \\
\text { a given track. Wind speed accuracy is } 1 \mathrm{~m} \mathrm{~s}^{-1} \text { (Holland et al., 1992; McGeer and Holland, 1993). }\end{array}$} \\
\hline $\begin{array}{l}\text { Skin } \\
\text { temperature }\end{array}$ & $\begin{array}{l}\text { Everest Mini-Therm } \\
\text { Infrared Thermometer } \\
\text { (various versions of } \\
\text { 3800L) }\end{array}$ & $\begin{array}{l}\text { Minimum: }-18^{\circ} \mathrm{C} \text { or } \\
-45^{\circ} \mathrm{C} \text { depending on } \\
\text { model }(300 \mathrm{~m} \text { maximum } \\
\text { operating distance) }\end{array}$ & $0.2^{\circ} \mathrm{C}$ & $0.2 \mathrm{~Hz}$ & $0.75 \mathrm{~s}$ \\
\hline
\end{tabular}

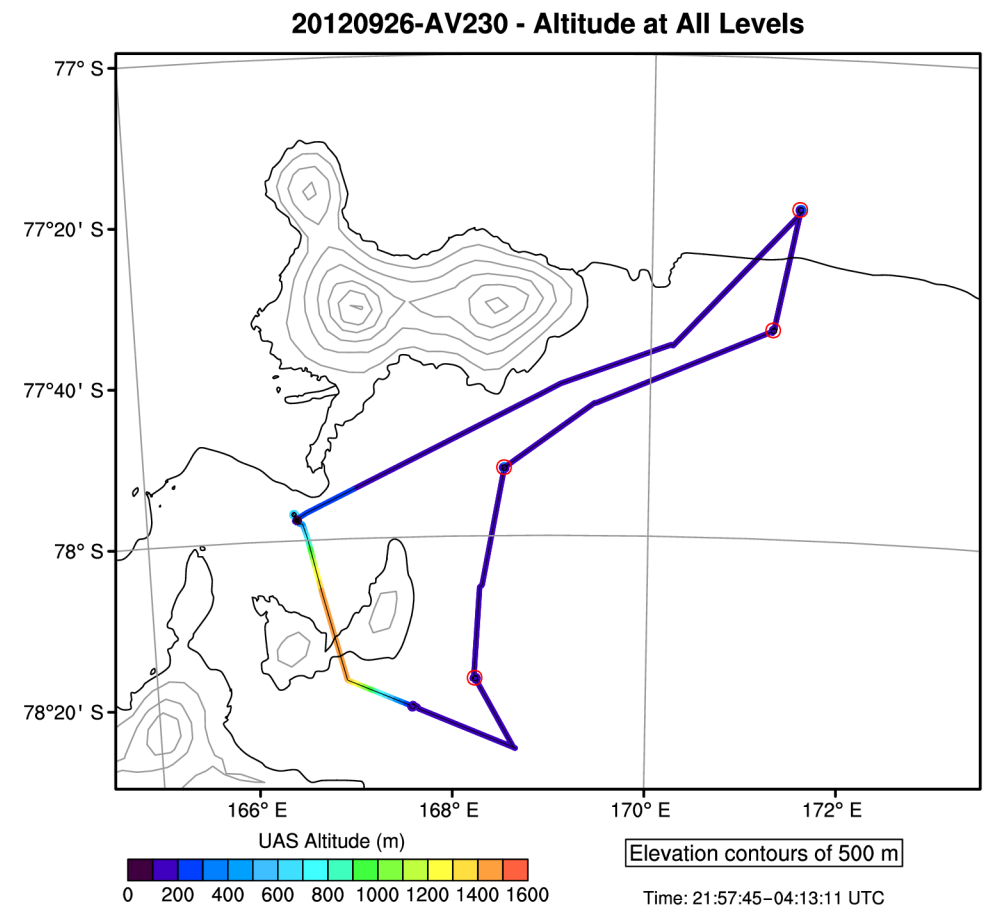

Figure 4. Map of Ross Ice Shelf and Ross Sea flight 26 September 2012 AV230. Color shading along flight path indicates flight altitude. Red circles indicate location of profiles.

sects in Table 3 and subsequent text. For these missions an Aerosonde UAS flew horizontal flight legs roughly perpendicular to the low level flow. Spiral ascent and descent profiles extending above the depth of the boundary layer were flown at the end and mid-points of some of these horizontal transect flights.

Of the 11 flights to TNB, 10 flights were completed on 5 flight days, with two Aerosonde UAS flying over the
TNB polynya at the same time. Neither of the flights on 14 September 2012 (Fig. 3b, c) made it to TNB due to problems with the Aerosondes. This flight strategy allowed one UAS to focus on observing the downstream evolution of the continental air mass while the second UAS observed the crosswind variability in the atmospheric state. The observations from these pairs of UAS flights provide a compre- 
Table 3. Summary of Aerosonde UAS flights during September 2012 including start and end time and date of each flight, aircraft number, primary flight destination, flight type (see text for additional details), and additional comments describing flight transect heights and number and altitude range of profiles.

\begin{tabular}{|c|c|c|c|c|c|}
\hline $\begin{array}{l}\text { Start } \\
\text { time/date }\end{array}$ & $\begin{array}{l}\text { End } \\
\text { time/date }\end{array}$ & $\begin{array}{l}\text { Aircraft } \\
\text { number }\end{array}$ & $\begin{array}{l}\text { Primary } \\
\text { destination }\end{array}$ & Flight type & Additional comments \\
\hline $\begin{array}{l}\text { 00:00 UTC } \\
9 \text { Sep }\end{array}$ & $\begin{array}{l}\text { 03:29 UTC } \\
\text { 9 Sep }\end{array}$ & AV 230 & Pegasus & Test flight & Limited scientific data \\
\hline $\begin{array}{l}0449 \text { UTC } \\
9 \text { Sep }\end{array}$ & $\begin{array}{l}\text { 0507 UTC } \\
9 \text { Sep }\end{array}$ & AV 214 & Pegasus & Test flight & $\begin{array}{l}\text { Limited scientific data. Aborted flight due to } \\
\text { high engine temperature. }\end{array}$ \\
\hline $\begin{array}{l}\text { 04:17 UTC } \\
13 \text { Sep }\end{array}$ & $\begin{array}{l}\text { 18:44 UTC } \\
13 \text { Sep }\end{array}$ & AV 214 & TNB & $\begin{array}{l}\text { Crosswind } \\
\text { transect }\end{array}$ & $\begin{array}{l}\text { Lost communications, one coast parallel tran- } \\
\text { sect only }\end{array}$ \\
\hline $\begin{array}{l}\text { 04:36 UTC } \\
14 \text { Sep }\end{array}$ & $\begin{array}{l}\text { 16:23 UTC } \\
14 \text { Sep }\end{array}$ & AV 216 & TNB & $\mathrm{n} / \mathrm{a}$ & $\begin{array}{l}\text { Lost communications, crashed at Windless } \\
\text { Bight due to suspected icing of pitot tube. }\end{array}$ \\
\hline $\begin{array}{l}\text { 06:08 UTC } \\
14 \text { Sep }\end{array}$ & $\begin{array}{l}\text { 18:53 UTC } \\
14 \text { Sep }\end{array}$ & AV 230 & TNB & $\mathrm{n} / \mathrm{a}$ & $\begin{array}{l}\text { Lost communications, majority of flight in } \\
\text { vicinity of Ross Island, surface temperature } \\
\text { data available for } 18.9 \% \text { of flight }\end{array}$ \\
\hline $\begin{array}{l}\text { 04:30 UTC } \\
18 \text { Sep }\end{array}$ & $\begin{array}{l}\text { 20:37 UTC } \\
18 \text { Sep }\end{array}$ & AV 215 & TNB & $\begin{array}{l}\text { Downwind } \\
\text { transect }\end{array}$ & $\begin{array}{l}\text { Downwind transect at } 100 \mathrm{~m} \text { a.g.l., } 8 \text { profiles } \\
\text { from } 100 \text { to } 1600 \mathrm{~m} \text { a.g.1., each profile location } \\
\text { repeated twice }\end{array}$ \\
\hline $\begin{array}{l}05: 41 \mathrm{UTC} \\
18 \mathrm{Sep}\end{array}$ & $\begin{array}{l}\text { 20:04 UTC } \\
18 \text { Sep }\end{array}$ & AV 230 & TNB & $\begin{array}{l}\text { Crosswind } \\
\text { transect }\end{array}$ & $\begin{array}{l}4 \text { crosswind transects and } 1 \text { downwind transect } \\
\text { at } 100 \mathrm{~m} \text { a.g.1., surface temperature data avail- } \\
\text { able for } 6.8 \% \text { of flight }\end{array}$ \\
\hline $\begin{array}{l}\text { 04:06 UTC } \\
\text { 19 Sep }\end{array}$ & $\begin{array}{l}\text { 13:20 UTC } \\
19 \text { Sep }\end{array}$ & AV 215 & TNB & $\begin{array}{l}\text { Downwind } \\
\text { transect }\end{array}$ & $\begin{array}{l}4 \text { profiles from } 100 \text { to } 1600 \mathrm{~m} \text { a.g.l., UAS } \\
\text { crashed in TNB due to generator belt failure }\end{array}$ \\
\hline $\begin{array}{l}\text { 05:20 UTC } \\
19 \text { Sep }\end{array}$ & $\begin{array}{l}\text { 20:18 UTC } \\
19 \text { Sep }\end{array}$ & AV 242 & TNB & $\begin{array}{l}\text { Crosswind } \\
\text { transect }\end{array}$ & $\begin{array}{l}\text { Four crosswind transects and one downwind } \\
\text { transect at } 100 \text { to } 150 \mathrm{~m} \text { a.g.l., surface temper- } \\
\text { ature data available for } 32.0 \% \text { of flight }\end{array}$ \\
\hline $\begin{array}{l}\text { 03:15 UTC } \\
22 \text { Sep }\end{array}$ & $\begin{array}{l}\text { 21:16 UTC } \\
22 \text { Sep }\end{array}$ & AV 242 & TNB & $\begin{array}{l}\text { Downwind } \\
\text { transect }\end{array}$ & $\begin{array}{l}\text { Downwind transect at } 100 \mathrm{~m} \text { a.g.l., } 10 \text { profiles } \\
\text { from } 100 \text { to } 1600 \mathrm{~m} \text { a.g.1., each profile location } \\
\text { repeated twice, surface temperature data avail- } \\
\text { able for } 32.5 \% \text { of flight }\end{array}$ \\
\hline $\begin{array}{l}\text { 04:34 UTC } \\
22 \text { Sep }\end{array}$ & $\begin{array}{l}\text { 20:04 UTC } \\
22 \text { Sep }\end{array}$ & AV 230 & TNB & $\begin{array}{l}\text { Crosswind } \\
\text { transect }\end{array}$ & $\begin{array}{l}\text { Four crosswind transects at } 100 \mathrm{~m} \text { a.g.l. with } \\
\text { profiles from } 100 \text { to } 1600 \mathrm{~m} \text { a.g.l. at southern, } \\
\text { middle, and northern end of transects, surface } \\
\text { temperature data available for } 35.2 \% \text { of flight }\end{array}$ \\
\hline $\begin{array}{l}\text { 02:29 UTC } \\
25 \mathrm{Sep}\end{array}$ & $\begin{array}{l}\text { 18:39 UTC } \\
25 \text { Sep }\end{array}$ & AV 242 & TNB & $\begin{array}{l}\text { Downwind } \\
\text { transect }\end{array}$ & $\begin{array}{l}\text { Downwind transect at } 100 \mathrm{~m} \text { a.g.l., } 8 \text { profiles } \\
\text { from } 100 \text { to } 1600 \mathrm{~m} \text { a.g.1., surface temperature } \\
\text { data available for } 47.0 \% \text { of flight }\end{array}$ \\
\hline $\begin{array}{l}\text { 04:33 UTC } \\
25 \text { Sep }\end{array}$ & $\begin{array}{l}\text { 18:58 UTC } \\
25 \text { Sep }\end{array}$ & AV 230 & TNB & $\begin{array}{l}\text { Crosswind } \\
\text { transect }\end{array}$ & $\begin{array}{l}\text { Three crosswind transects at } 100 \mathrm{~m} \text { a.g.l. with } \\
\text { profiles from } 100 \text { to } 1600 \mathrm{~m} \text { a.g.l. at southern, } \\
\text { middle, and northern end of transects, surface } \\
\text { temperature data available for } 33.4 \% \text { of flight }\end{array}$ \\
\hline $\begin{array}{l}21: 57 \text { UTC } \\
26 \text { Sep }\end{array}$ & $\begin{array}{l}\text { 04:13 UTC } \\
27 \text { Sep }\end{array}$ & AV 230 & $\begin{array}{l}\text { Ross ice shelf/ } \\
\text { Ross Sea polynya }\end{array}$ & $\begin{array}{l}\text { Ross Ice Shelf air } \\
\text { stream transects }\end{array}$ & $\begin{array}{l}\text { Transects from Pegasus to east of Ross Is- } \\
\text { land at } 160 \mathrm{~m} \text { a.g.l. with } 4 \text { profiles from } 160 \text { to } \\
1600 \mathrm{~m} \text { a.g.l. }\end{array}$ \\
\hline
\end{tabular}

hensive three-dimensional observational data set of the atmospheric state over the TNB polynya.

The remaining three flights (Table 3 ) were either local test flights over the Pegasus ice runway (not shown) or a flight of opportunity to sample the Ross Ice Shelf air stream and Ross Sea polynya located east and northeast of the Pegasus runway (Fig. 4).

\subsection{Examples of observed features}

Figure 5 shows four temperature and dew point profiles collected during the downwind transect flight of AV242 on 22 September 2012 (Fig. 3h). The profiles were measured at $5,15,30$, and $43 \mathrm{~km}$ downwind from the coast. The nearsurface atmosphere warms more than $2{ }^{\circ} \mathrm{C}$ over the $38 \mathrm{~km}$ represented by these profiles indicating the warming of the air mass as it crosses the polynya. The temperature profiles for all four locations show a nearly dry adiabatic lapse rate, 


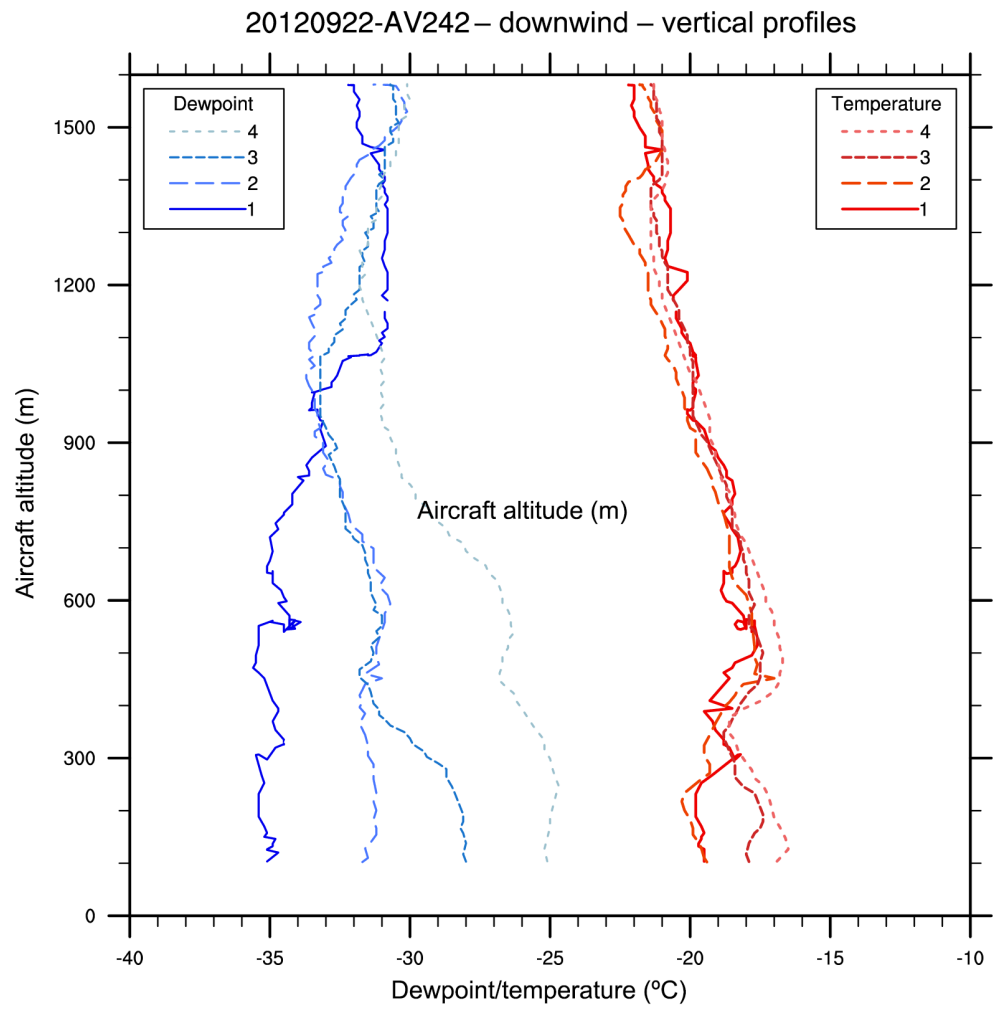

Figure 5. Sample of profile data - temperature and dew point at four vertical ascent profiles from 22 September 2012 AV 242 . The profiles start $5 \mathrm{~km}$ from the coast and continue downwind.

consistent with convection over the relatively warm open water. The depth of this convective layer extends from $100 \mathrm{~m}$ at profile 1 to $300 \mathrm{~m}$ at profile 4 , indicating a deepening of the boundary layer with downstream distance over the polynya. The dew point increases by $10^{\circ} \mathrm{C}$ over the $38 \mathrm{~km}$ indicating a moistening of the boundary layer air with the addition of water vapor from the open water of the polynya.

Figure 6 shows an example of the horizontal winds observed during a crosswind transect flight on 22 September 2012 . Wind speeds approaching $30 \mathrm{~m} \mathrm{~s}^{-1}$ are observed in the core of the offshore jet decreasing to only a few $\mathrm{m} \mathrm{s}^{-1}$ on the northern and southern edges of TNB. The color shading of the flight path indicates the air temperature. It can be seen that the air mass warms as it moves downwind away from the coast, as is also shown in the vertical profiles for the same day (Fig. 5).

Figure 7 shows sea and ice surface temperatures measured by two aircraft on one flight day ( 25 September). The slight overall decrease in surface temperatures from west to east across the polynya shows the impact of increasing ice thickness across the area, as new ice forms at the west and thickens while being transported east across the polynya. Measurements from over glacier ice show how cold (below $-20^{\circ} \mathrm{C}$ ) the surface temperatures would be without the constant heat flux from the ocean below.

\section{Data processing and quality control}

The observations on the UAS were collected using an onboard datalogger. The observations were telemetered back to ground stations at Pegasus Field and McMurdo Station in real-time as well as stored on the UAS. The processed and archived observations were taken from the onboard data storage. The two exceptions to this are the flights (AV216 14 September 2012; AV 215 - 19 September 2012) that did not return to Pegasus Field. For those two flights the source of the observation data is the telemetered data that were received at the ground stations. The two flights with telemetered data have incomplete data with AV216 - 14 September 2012 starting at an altitude of $760 \mathrm{~m}$ and both flights having frequent missing data sections lasting approximately $200 \mathrm{~s}$.

The initial collection of observations was in the form of spreadsheet files with a single sheet including all of the observations for a given flight. Post-processing of the data was completed to reformat the observations, add metadata, and write netCDF and ASCII text formatted files for distribution but no corrections to the data were applied. The data were reformatted to set the level of precision (number of digits to the right of the decimal point) to match that of the instrument. The time was reformatted to a UDUNITS (http://www.unidata.ucar.edu/software/udunits/) conforming 
20120922-AV230 - temperature at $103 \mathrm{~m}$

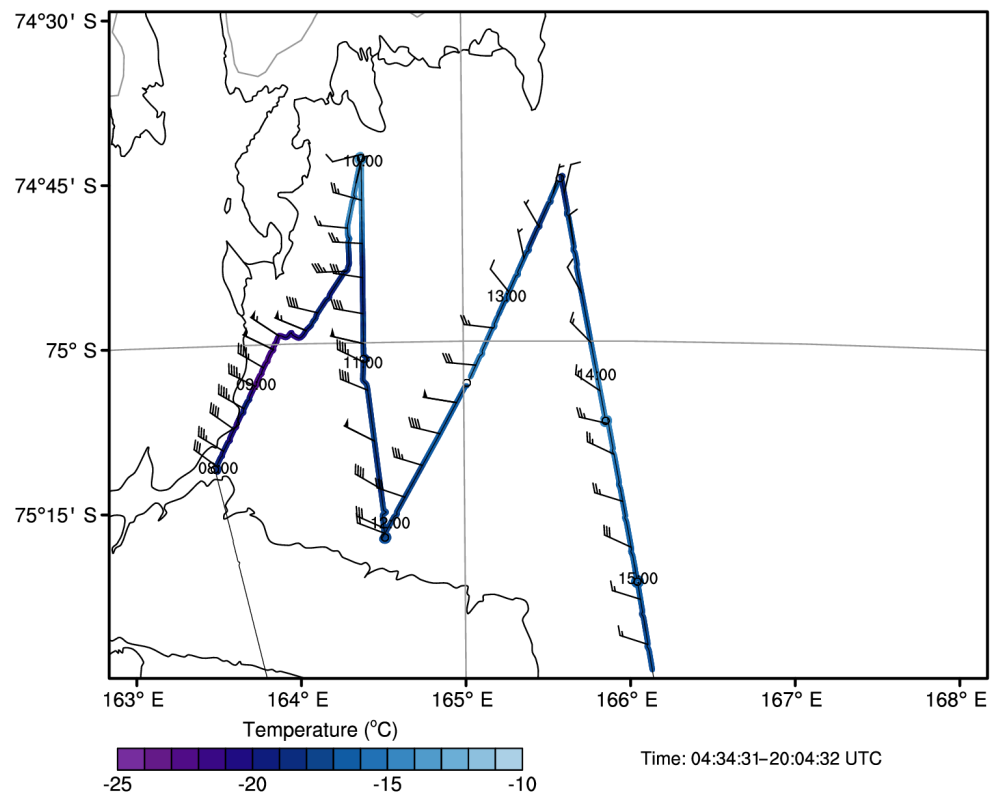

Figure 6. Sample of spatial plot - horizontal winds over TNB at $103 \pm 10 \mathrm{~m}$ flight level 22 September 2012 AV 230 . Wind barbs are plotted with a half-barb $=2.5 \mathrm{~m} \mathrm{~s}^{-1}$ and a full-barb $=5.0 \mathrm{~m} \mathrm{~s}^{-1}$. The color shading indicates air temperature at flight level.

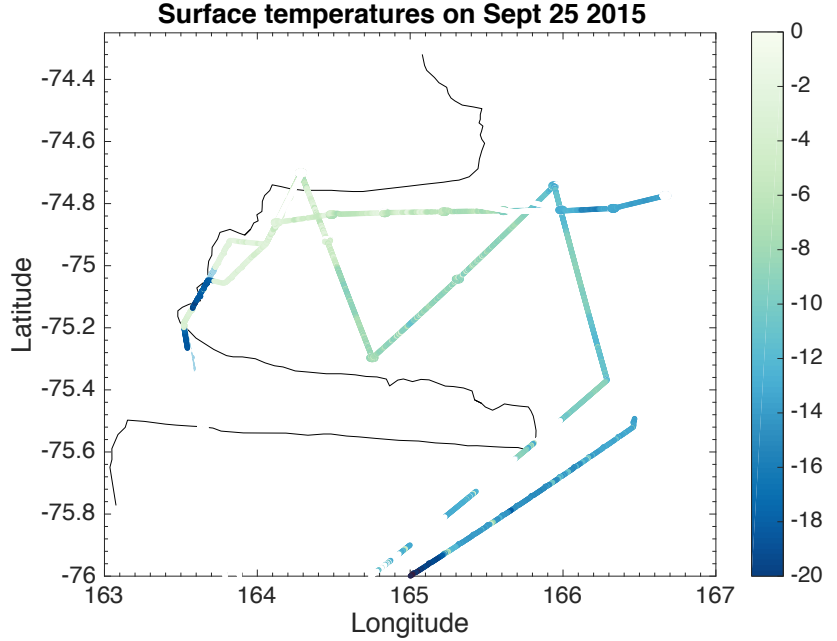

Figure 7. Surface temperature data for the two flights on 25 September 2012 (AV 230 and AV242), plotted over the outline of the polynya area (black line).

time unit of "seconds since 2012-09-01 00:00:00". Additional time integer fields of year, month, day, hour, minute, and second were created for ease of use. Metadata fields were added to fully self-describe the data within the netCDF files. The metadata fields were created to comply with ClimateForecast (CF) conventions (http://cfconventions.org/) for trajectory observations. Specifically, CF metadata for standard_name, long_name, and units were included for each variable.
The primary atmospheric state variables that were measured included pressure, temperature, and relative humidity. A manual quality control review of these observations found the values to be reasonable and within the range of expectations. The exceptions to this are the AV242 flights where approximately three to eight datapoints of temperature and relative humidity were removed for each flight due to unrealistic values being reported. The telemetered flights (AV216 - 14 September 2012; AV 215 - 19 September 2012) have questionable observations around the gaps in missing observations. Values for dew point and mixing ratio were calculated in the post-processing from temperature, relative humidity, and pressure. These additional measures of atmospheric moisture were included to provide other options for atmospheric analyses. The observations of wind speed and wind direction were determined from the UAS avionics measurements of ground speed, track, and true air speed. Additionally, the aircraft heading is determined when the UAS changes course. The UAS wind-finding algorithm uses a regression fit based on these measurements to determine the values for wind speed and wind direction. The estimates degrade over time while the UAS maintains a given track. To compensate for this degradation, periodic "wind finding" maneuvers were performed when flying along a given track to determine the aircraft heading. Holland et al. (1992) and McGeer and Holland (1993) used a similar method to determine wind speed and direction using Aerosonde UAS and noted a wind speed accuracy of $1 \mathrm{~m} \mathrm{~s}^{-1}$.

No observations were removed during the quality control step for the UAS GPS observations of latitude and longi- 
tude. A careful review was completed for all of the observation points for each of the flights. The latitude and longitude observations are very consistent, as would be expected with the high horizontal temporal resolution in comparison to the variability of position over time for the UAS. There are occasional small variations in the data that are an intentional part of the flight maneuvers in order to most accurately determine the wind speed and wind direction as described above. These wind finding maneuvers occur with approximately $4 \mathrm{~min}$ intervals when the UAS is flying along a straight course. The UAS GPS altitude, the altitude above the GPS reference geoid, was corrected by computing the point geoid height values using a spherical harmonic potential coefficient (EGM96) and a spherical harmonic correction coefficient (CORRCOEF) (details: http://earth-info.nga. $\mathrm{mil} / \mathrm{GandG} / \mathrm{wgs} 84 /$ gravitymod/egm96/egm96.html). The altitude measurements have variation in the measurements in the range of at least $\pm 0.5 \mathrm{~m}$ and as high as $\pm 1.0 \mathrm{~m}$ in some locations. This variability is due to the lower resolution of GPS altitude measurements and the reality that the UAS is frequently experiencing minor variations in altitude due to atmospheric turbulence and vertical motions. In apparently turbulent locations there appears to be even greater range and variation in altitude. The decision was made to include all of the altitude observations as there is a high likelihood that the variations in height are real. Additional UAS observations of ground speed, ground direction, barometric altitude, roll, pitch, and yaw are included in the data set but these values have not been reviewed or quality controlled.

For all 14 flights more than $98 \%$ of the possible pressure, temperature, humidity, wind speed and wind direction values and all of the GPS and aircraft flight data are available in the quality-controlled data set. Surface temperature data are available for 7 of the 14 flights but quality-controlled data are present for just over $30 \%$ of the flight time for 5 of the flights and for less than $20 \%$ of the flight time for 2 of the flights (Table 3).

\section{Data availability}

The data files for each flight are available from the United States Antarctic Program Data Center (http://gcmd.nasa.gov/ getdif.htm?NSF-ANT10-43657, doi:10.15784/600125). The data are posted by individual flight days and aircraft for a total of 14 available data sets for the 14 different flights. NetCDF and ASCII versions of the data set are provided for each flight. The netCDF files have each variable listed individually with an array length equal to that of the number $5 \mathrm{~s}$ observations. Self-describing metadata are also included to provide information on the source and units for the data. The ASCII file contains columns of data for each variable and the number of lines matches the number of $5 \mathrm{~s}$ observations. No metadata are included with the ASCII file. An image of the flight path and altitude are provided for each flight to provide a visual depiction of the region covered by each flight (the same figures that are included in Figs. 3 and 4).

\section{Summary}

In September 201214 Aerosonde unmanned aerial system (UAS) flights were made in the vicinity of McMurdo Station and Terra Nova Bay, Antarctica, totaling more than 168 flight hours. Ten of the flight missions consisted of two UAS sampling the atmosphere over Terra Nova Bay on five different days, with one UAS focusing on the downwind evolution of the air mass and a second UAS flying transects roughly perpendicular to the low-level winds. The flights consisted of both long segments (order $10 \mathrm{~km}$ ) at constant height and multiple spiral profiles from flight level $(\sim 100 \mathrm{~m}$ a.g.l. $)$ to above the top of the boundary layer $(1600 \mathrm{~m}$ a.g.l). The goal of these flights was to observe the atmosphere and surface state over Terra Nova Bay and to explore the details of airsea ice-ocean coupling. The data from these coordinated UAS flights provide a comprehensive three-dimensional data set of the atmospheric state (air temperature, humidity, pressure, and wind) and surface skin temperature over Terra Nova Bay. The remaining UAS flights during the September 2012 field campaign included two local flights near McMurdo Station for flight testing, a single UAS flight to Terra Nova Bay, and a single UAS flight over the Ross Ice Shelf and Ross Sea polynya. A quality-controlled data set containing the atmospheric and surface data as well as operational aircraft data have been submitted to the United States Antarctic Program Data Coordination Center (USAP-DCC, http://www.usap-data.org/) for free access (http://gcmd.nasa. gov/getdif.htm?NSF-ANT10-43657, doi:10.15784/600125).

Author contributions. J. J. Cassano was the lead investigator on this project and supervised all flights during the 2012 field campaign. M. W. Seefeldt was responsible for the data processing, quality control, and posting to the repository. S. Palo was responsible for instrumentation issues and liaising with Aerosonde Pty. Ltd. S. L. Knuth assisted J. J. Cassano with flight operations and forecasting for flights and she also performed the initial data processing and review of the data. A. C. Bradley was responsible for surface temperature data processing and quality control. P. D. Herrman, P. A. Kernebone, and N. J. Logan provided, maintained, and flew the Aerosonde UASs.

Acknowledgements. This work was supported by NSF grant ANT 1043657. The authors wish to thank the United States Antarctic Program support personnel for all of their help during the September 2012 field campaign.

Edited by: G. König-Langlo 


\section{References}

Bromwich, D. H.: An extraordinary katabatic wind regime at Terra Nova Bay, Antarctica, Mon. Weather Rev., 117, 688-695, doi:10.1017/S095410200300110X, 1989.

Bromwich, D. H. and Kurtz, D. D.: Katabatic wind forcing of the Terra Nova Bay polynya, J. Geophys. Res., 89, 3561-3572, 1984.

Bromwich, D. H., Parish, T. R., and Zorman, C. A.: The confluence zone of the intense katabatic winds at Terra Nova Bay, Antarctica as derived from airborne sastrugi surveys and mesoscale numerical modeling, J. Geophys. Res., 95, 5495-5509, 1990.

Bromwich, D. H., Carrasco, J. F., Liu, Z., and Tzeng, R. Y.: Hemisphere atmospheric variations and oceanographic impacts associated with katabatic surges across the Ross Ice Shelf, Antarctica, J. Geophys. Res., 98, 13045-13062, 1993.

Buffoni, G., Cappelletti, A., and Picco, P.: An investigation of thermohaline circulation in Terra Nova Bay polynya, Antarct. Sci., 14, 83-92, 2002.

Cappelletti, A., Picco, P., and Peluso, T.: Upper ocean layer dynamics and response to atmospheric forcing in the Terra Nova Bay polynya, Antarctica, Antarct. Sci., 22, 319-329, doi:10.1017/S095410201000009X, 2010.

Cassano, J. J., Maslanik, J. A., Zappa, C. J., Gordon, A. L., Cullather, R. I., and Knuth, S. L.: Observations of an Antarctic polynya with unmanned aircraft systems, Eos, 91, 245-246, 2010.

Ciappa, A., Pietranera, L., and Budillon, G.: Observations of the Terra Nova Bay (Antarctica) polynya by MODIS ice surface temperature imagery from 2005 to 2010, Remote Sens. Environ., 199, 158-172, 2012.

Curry, J. A., Maslanik, J., Holland, G., and Pinto, J.: Applications of aerosondes in the Arctic, B. Am. Meteorol. Soc., 85, 1855-1861, 2004.

Fusco, G., Budillon, G., and Spezie, G.: Surface heat fluxes and thermohaline variability in the Ross Sea and Terra Nova Bay polynya, Cont. Shelf. Res., 29, 1887-1895, 2009.

Gallee, H. and Schayes, G.: Development of a Three-dimensional meso-gamma primitive equation model: Katabatic wind simulation in the area of Terra Nova Bay, Antarctica, Mon. Weather Rev., 122, 671-685, 1994.

Grigioni, P.: The Italian Antarctic meteorological observatory: technical activity and some climatological results, in: Italian Geophysical observatories in Antarctica, edited by: Meloni, A. and Morelli, A., Compositori, Bologna, 135-149, 1996.

Hauser, A., Lythe, M., and Wendler, G.: Sea-ice conditions in the Ross Sea during spring 1996 as observed on SAR and AVHRR imagery, Atmos. Ocean, 40, 281-292, 2002.

Holland, G. J., McGeer, T., and Youngren, H.: Autonomous Aerosondes for economical atmospheric soundings anywhere on the globe, B. Am. Meteorol. Soc., 73, 1987-1998, 1992.

Holland, G. J., Webster, P. J., Curry, J. A., Tyrell, G., Gauntlett, D., Brett, G., Becker, J., Hoag, R., and Vaglienti, W.: The Aerosonde robotic aircraft: A new paradigm for environmental observations, B. Am. Meteorol. Soc., 82, 889-901, 2001.
Inoue, J. and Curry, J. A.: Application of Aerosondes to high-resolution observations of sea surface temperature over Barrow Canyon, Geophys. Res. Lett., 31, L14312, doi:10.1029/2004GL020336, 2004.

Inoue, J., Curry, J. A., and Maslanik, J. A.: Application of Aerosondes to melt-pond observations over Arctic sea ice, J. Atmos. Ocean. Tech., 25, 327-334, 2008.

Kern, S. and Aliani, S.: A comparison between polynya area and associated ice production with mooring-based measurements of temperature, salinity and currents in the southwestern Ross Sea, Antarctica, Ann. Glaciol., 52, 291-300, 2011.

Knuth, S. L. and Cassano, J. J.: Estimating sensible and latent heat fluxes using the integral method from in situ aircraft measurements, J. Atmos. Ocean. Tech., 31, 1964-1981, 2014.

Knuth, S. L., Cassano, J. J., Maslanik, J. A., Herrmann, P. D., Kernebone, P. A., Crocker, R. I., and Logan, N. J.: Unmanned aircraft system measurements of the atmospheric boundary layer over Terra Nova Bay, Antarctica, Earth Syst. Sci. Data, 5, 57-69, doi:10.5194/essd-5-57-2013, 2013.

Kurtz, D. D. and Bromwich, D. H.: Satellite observed behavior of the Terra Nova Bay polynya, J. Geophys. Res., 88, 9717-9722, 1983.

Lazzara, M. A., Weidner, G. A., Keller, L. M., Thom, J. E., and Cassano, J. J.: Antarctic automatic weather station program: 30 years of polar observations, B. Am. Meteorol. Soc., 93, 15191537, doi:10.1175/BAMS-D-11-00015.1, 2012.

McGeer, T. and Holland, G. J.: Small autonomous aircraft for economical oceanographic observations on a wide scale, Oceanography, 6, 129-135, 1993.

Morales Maqueda, M. A., Willmott, A. J., and Biggs, N. R. T.: Polynya dynamics: A review of observations and modeling, Rev. Geophys., 42, RG1004, doi:10.1029/2002RG000116, 2004.

Orsi, A. H. and Wiederwohl, C. L.: A recount of Ross Sea waters, Deep-Sea Res. Pt. II, 56, 778-795, 2009.

Parish, T. R. and Bromwich, D. H.: Instrumented aircraft observations of the katbatic wind regime near Terra Nova Bay, Mon. Weather Rev., 117, 1570-1585, 1989.

Petrelli, P., Bindoff, N. L., and Bergamasco, A.: The sea ice dynamics of Terra Nova Bay and Ross Ice Shelf polynyas during a spring and winter simulation, J. Geophys. Res., 113, C09003, doi:10.1029/2006JC004048, 2008.

Rusciano, E., Budillon, G., Fusco, G., and Spezie, G.: Evidence of atmosphere-sea ice-ocean coupling in the Terra Nova Bay polynya (Ross Sea - Antarctica), Cont. Shelf. Res., 61-62, 112124, 2013.

van Woert, M. L.: Wintertime dynamics of the Terra Nova Bay polynya, J. Geophys. Res., 104, 7753-7769, 1999. 